\title{
摘出胆囊に打汀る化生の臨床病理学的検討
}

一特に胆囊癌組織発生の背景として一

久留米人学第 2 外科（主仕: 古賀道弘教授)

平井点朗

CLINICOPATHOLOGICAL STUDY ON METAPLASIA

IN RESECTED GALLBLADDER

-AS A BACKGROUND OF HISTOGENESIS OF GALLBADDER CANCER-

\section{Sadaaki HIRAI}

The 2nd Department of Surgery, Kurume University School of Medicine

(Prof Michihiro Koga)

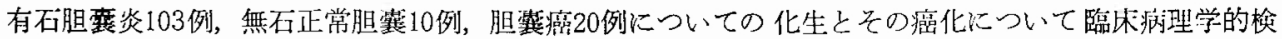
索を行った．その結果有石例はテープ緑变例（蔗糖分解醇素の発見）13例 (12.6\%), 偽幽門腺55例 (53.4 $\%)$ ，杯細胞33例 $(32.0 \%)$ ，EC 細胞12例 $(11.7 \%)$ ，Paneth 細胞 3 例 $(2.9 \%)$ の出現を見，無石例は 偽幽門腺, 杯細胞が各 I 例 (10.0\%) であった. 分化型胆营癌16例中腫瘍内に12例 $(75.0 \%)$ の杯細胞が みられ，さらに腸型吸収上皮の存在するものがあった。化生と分化型癌は諸検查に共通性があり，正常胆

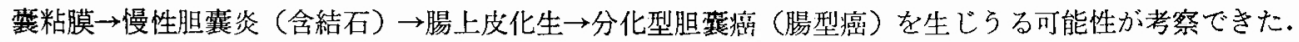

索引用語：腸上皮化生, 並糖分解酵素, 腸型吸収上皮, 分化型胆露癌（腸型癌）

I)はじめに

胆䨢は解剖学的に癌が進行しやすい構造をしており， 治癒可能な時期に症状がなく一旦症状が出たときは進行 例であることが多い，早期診断には血清や尿などによる 特買的な倹畣法の発見が理想的であるが，その方法がな い現在において著者は摘出胆慗において肉眼的, 生化学 的, 組織学的, 電影学的に検索し, 胃においては一般的 な所見である腸上皮化生の考方年胆囊に導入し，蔗糖 分解酵素を発見した。また，それら化生粘膜と胆製癌の 関速性についても検钶乙興味ある結果を得たので，これ が早期胆㐮癌診断法の糸口になれば幸いである。

\section{II) 検查材料}

1977年11月より1978年.8月までに久留米大学第二外科 及び夙連病院において有石胆囊炎の診断のもとに摘出さ れた胆衰103例（男性43例，女性60例，平均年齢51.0歳） 対照として他疾患で合併切除された無石正常胆震10例 （男性 7 例，女性 3 例，平均年齢59.0歳）計113例につ
いて検討を行った。な技胆囊湾は久留米大学第二外科に おいて摘出し諸検查ができた 20 例について検討した。

\section{III) 検查方法}

摘出胆装はただらに肝床部面にて頝部から底部への切 開を加え電顕用切片を採取した後生理的食塩水による充 分な洗浄を施行し田中"号の方法にしたがいテステープ による晹上皮化生の生化学的検索を行った，そして写真 掫影後10\%ホルマリンに固定し数日後10３0枚の胆囊 短軸平平行な階段切片を作製し鏡检した。染出はまず Hematoxylin-Eosin 染色を行い必要に応じて periodic acid-Schiff (PAS 染色), Alcian-blue (AB 染色), PASAB 重染绝, Masson-Fontana, Grimelius 法等の染色も行 った。な和摘出胆囊の粘膜の変化を今永 ${ }^{2}$ ，に準じ肉眼 的に正常より高度胆襄炎までその病变の度合で I IV度 に分類し諸検查を施行した。

\section{IV) 検查成繶}

A) 肉眼的分類 (表 1 ) 
表 1 摘出胆囊粘膜の肉眼的分類 103 例

\begin{tabular}{|c|c|c|c|}
\hline 肉眼分類 & \multicolumn{2}{|c|}{ 肉眼的形状 } & $\begin{array}{c}\text { 症例数 } \\
(\%)\end{array}$ \\
\hline I 度 & 正 常 型 & 粘膜は殆んど正常 & $\left(\begin{array}{c}3 \\
(2.9)\end{array}\right.$ \\
\hline II 度 & 炎症軽度型 & 軽い炎症性変化 & $\begin{array}{c}56 \\
(54.4)\end{array}$ \\
\hline III 度 & 炎症高度型 & $\begin{array}{l}\text { 強い炎症性変化 } \\
\text { 粘膜軽度脱落 }\end{array}$ & $\begin{array}{c}27 \\
(26.2)\end{array}$ \\
\hline IV 度 & 粘膜欠損型 & $\begin{array}{l}\text { 正常粘膜なし } \\
\text { 完全楾維化 }\end{array}$ & $\begin{array}{c}17 \\
(16.5)\end{array}$ \\
\hline
\end{tabular}

1977. $11 \sim 1978.8$

写真 1 テステープによる生化学的検索, 胆囊底部 が緑変 (蔴糖分解酵素)

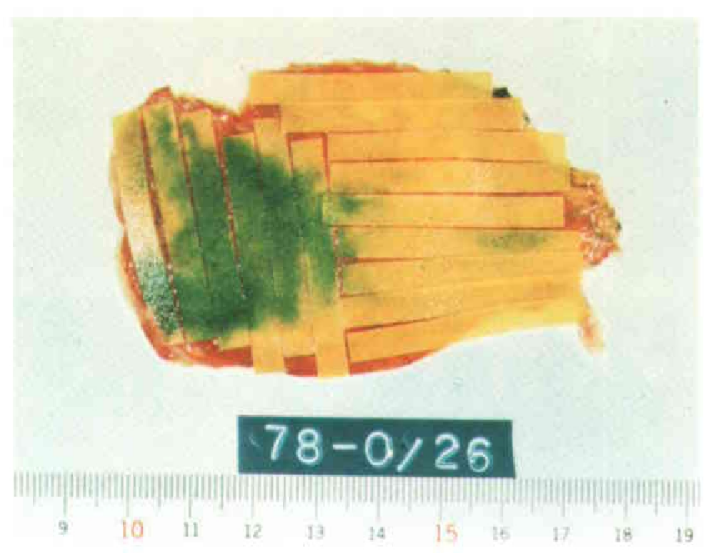

諸検查に先だちまず胆囊粘膜の肉腿的所見を表 1 のよ うに定めた。軽い炎症性変化の II 度が56例（54.4\%) と 最も多く, 対照群10例は I 度 3 例, II 度 7 例でIII, IV度 はなかった。

B）テステープによる生化学的検討（写真 1, 表 2, 3,4 )

蔗糖分解酵素の存在する部位におこるテープの緑色変
表 2 異所性粘膜検出頻度と年令

\begin{tabular}{|c|c|c|c|}
\hline & 拾出例数 & 男：女 & $\begin{array}{l}\text { 平均年齢 } \\
\text { (歲) }\end{array}$ \\
\hline $\begin{array}{l}\text { テステープ } \\
\text { 緑色変化 }\end{array}$ & $13(12.6)$ & $3: 10$ & 58.9 \\
\hline 偽幽門腺 & $55(53.4)$ & $2: 3$ & 55.0 \\
\hline 杯 細 胞 & $33(32.0)$ & $1: 2$ & 57.0 \\
\hline E. C 細胞 & $12(11.7)$ & $1: 2$ & 57.8 \\
\hline Paneth細胞 & $3(2.9)$ & $0: 3$ & 50.0 \\
\hline 全 症 例 & 103 & $2: 3$ & 51.0 \\
\hline \multicolumn{4}{|c|}{$\begin{array}{l}\text { E. C 細胞(腸ク口ム親和細胞) } \\
\text { ）％ }\end{array}$} \\
\hline
\end{tabular}

表 3 肉眼的分類と異所性粘膜との対比

\begin{tabular}{|c|c|c|c|c|}
\hline 異所性粘膜 & I 度 & II 鹿 & $\frac{\text { 巠㦄 }}{27 \text { 列 }}$ & $\begin{array}{l}\text { IN 度 } \\
17 \text { 例 }\end{array}$ \\
\hline $\begin{array}{l}\text { テステープ } \\
\text { 緑色変化 }\end{array}$ & 0 & $3(5.4)$ & $10(37.0)$ & 0 \\
\hline 偽幽門腺 & $1(33.3)$ & $33(58.9)$ & $19(70.4)$ & $2(11.8)$ \\
\hline 杯 細 胞 & 0 & $13(23.2)$ & $17(63.0)$ & $3(17.6)$ \\
\hline E. C 細胞 & 0 & $6(10.7)$ & $6(22.2)$ & 0 \\
\hline Paneth細胞 & 0 & $3(5.4)$ & 0 & 0 \\
\hline \multicolumn{3}{|c|}{$\begin{array}{l}\text { E. C 細胞 (腸クロム親和稩胞) } \\
(） \% 6\end{array}$} & 1977.11 & -1978. 8 \\
\hline
\end{tabular}

化は13例 (12.6\%) に見られ女性に多く, 年柃は30歳代 2 例，50歳代 4 例，60歳代 4 例， 70 歳代 3 例 平均年齢 58.9 歳であった（表 2 ). 肉眼所見と対比すると，とく に度では27例中10例（37.0\%）が变色したことになる (表 3 ). 変色の程度は濃〈変化するものから淡く変色 するものまでみられ，それが混在したり単独にも存在し ていた．変色部位についてみると胆跓全体にびまん性に

表 4 異所性粘膜の部位別症例数

\begin{tabular}{|c|c|c|c|c|c|c|c|c|}
\hline & 全体 & 頚部 & 体部 & 底 部 & 頝体部 & 体底部 & 頝底部 & 合計 \\
\hline $\begin{array}{l}\text { テステープ } \\
\text { 緑色変化 }\end{array}$ & $\begin{array}{c}5 \\
(38.5)\end{array}$ & $\begin{array}{c}2 \\
(15.4)\end{array}$ & 0 & $(23.0)$ & 0 & $\left(\begin{array}{l}1 \\
7.7\end{array}\right)$ & $\begin{array}{c}2 \\
(15.4)\end{array}$ & 13 \\
\hline 偽幽門腺 & $\begin{array}{c}14 \\
(25.5) \\
\end{array}$ & $\begin{array}{c}6 \\
(10.9)\end{array}$ & $\begin{array}{c}2 \\
(3.6)\end{array}$ & $\begin{array}{c}22 \\
(40.0)\end{array}$ & $\begin{array}{c}4 \\
(7.3)\end{array}$ & $\begin{array}{c}4 \\
(7.3)\end{array}$ & $\begin{array}{c}3 \\
(5.4)\end{array}$ & 55 \\
\hline 杯 紏 胞 & $\begin{array}{c}8 \\
(24.2)\end{array}$ & $\begin{array}{c}8 \\
(24.2)\end{array}$ & $\begin{array}{c}1 \\
(3.0)\end{array}$ & ${ }^{7}$ (21.3) & $\begin{array}{c}3 \\
(9.1)\end{array}$ & $\begin{array}{c}3 \\
(9.1)\end{array}$ & $\begin{array}{l}3 \\
(9.1)\end{array}$ & 33 \\
\hline E. C 細胞 & $(16.7)$ & $\begin{array}{c}2 \\
(16.7)\end{array}$ & 0 & $\begin{array}{c}5 \\
(41.7)\end{array}$ & $(8.3)$ & $\begin{array}{c}1 \\
(8.3)\end{array}$ & ( 13.3$)$ & 12 \\
\hline Paneth勫胞 & 0 & 0 & 0 & $\begin{array}{c}1 \\
(33.3)\end{array}$ & 0 & $\begin{array}{c}2 \\
(66.7)\end{array}$ & 0 & 3 \\
\hline
\end{tabular}

E. C 綝胞(腸ク口ム親和細胞)

1977. $11 \sim 1978.8$ 
写真 2
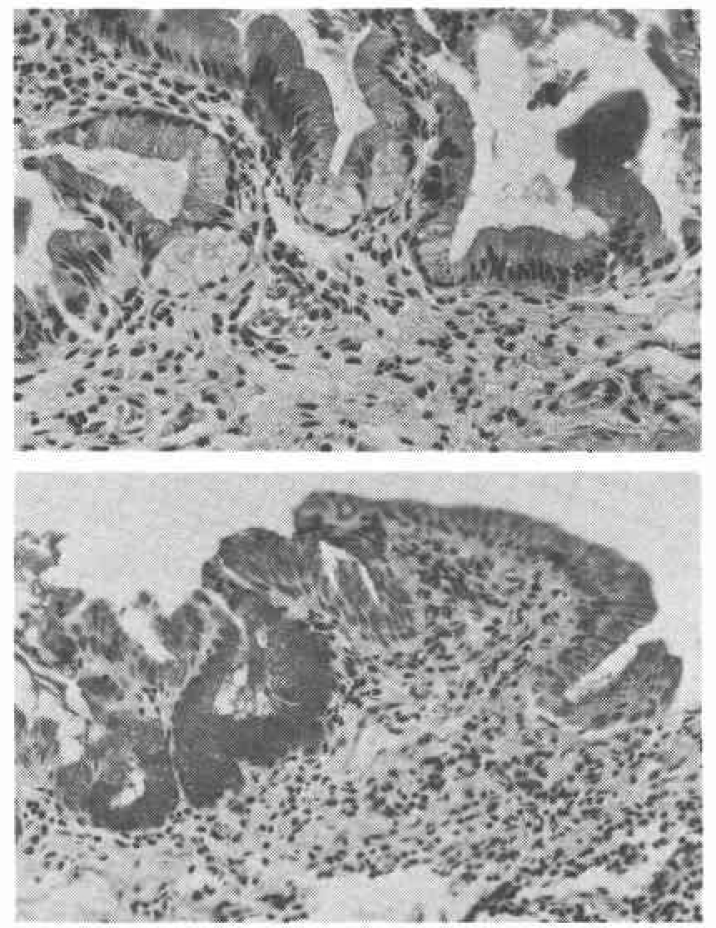

上 偽幽門腺管を作りつつある.末分化 (H-E染色)

下 PAS-AB 重染色. 腺简部では PAS 染色性が增強 $\times 100$

認める 5 例以外は巣状孤立性のものから，斑状に融合し たものまでさまざまであったが体部だけに変色をみた症 例はなかった（表 4). な和対照群には 1 例むテープの 変化を認めなかった。

C) 異所性粘膜の形態と分布

1）粘液腺化性（㑫幽門腺）（写卖 2，表 2，3，4）

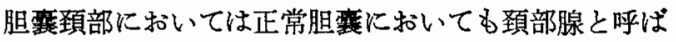
れる粘液腺が存在するがそれとは別化凩門腺がみられ た. 頻度は表 2 のごとくであり50〜70歳代の女性に特に 多い傾向を示した. 肉眼的分類との対比では偽罒門腺55 例中II 度に33例 $(60.0 \%)$ と多く，次いで目度に19例 (34.6\%)，I 度 1 例，IV度 2 例であった. 全症例で比 較すると表 3 のごとく正度にその頻度が高く炎症高度症 例に扣いてその発生頻度が高い結果であった。な扰対照 群では偽幽門腺は 1 例 $(10.0 \%)$ で䅡体部に軽度に認め られた末熟なものであった. 部位別では表 4 のごとく底 部に多く体部に少い傾向にあった。

正常粘膜からこの幽門腺への化生は腺窩部より発生す
ると考党られ，その部から夙幽門腺管胿を作りつつある 未分化な幽門腺をしばしば認めた（写真 2 上)。この幽 門腺化生の過程を PAS 染色, Alcianblue 染色および PAS-AB 重染色によって観察した，正常粘膜は PAS, $\mathrm{AB}$ 染色に扮いてとるに染色性をるち，その重染色では 青色に染むる微細な粘液顆粒をもつが腺窩部へ進むにし たがいその染色性は AB 染色性が低下し，逆に PAS 染 色性が増強し, 腺窩部では胞体内に PAS 強陽性の粘液 顆粒をるつた 細胞がみられた（写真 2 下）．そしてその 腺窩部周囲には，PAS 強陽性の偽幽門腺がみられた。

2）杯細胞（写乗 3，4，表 2，3，4）

i) 光顕的㰸索

頻度は表 2 に示すごとくであった. 肉眼的分類との対 比では杯細胞を䜅めた 33 例中度は17例 $(51.5 \%)$ と最 子多く次いでI 度が13例（39.4\%）でIV度は 3 例と少な く 1 度には認めなかった. 全症例については表 3 に示す ごとく偽幽門腺と同様に高度炎症例の正度に多かった。

写真 3
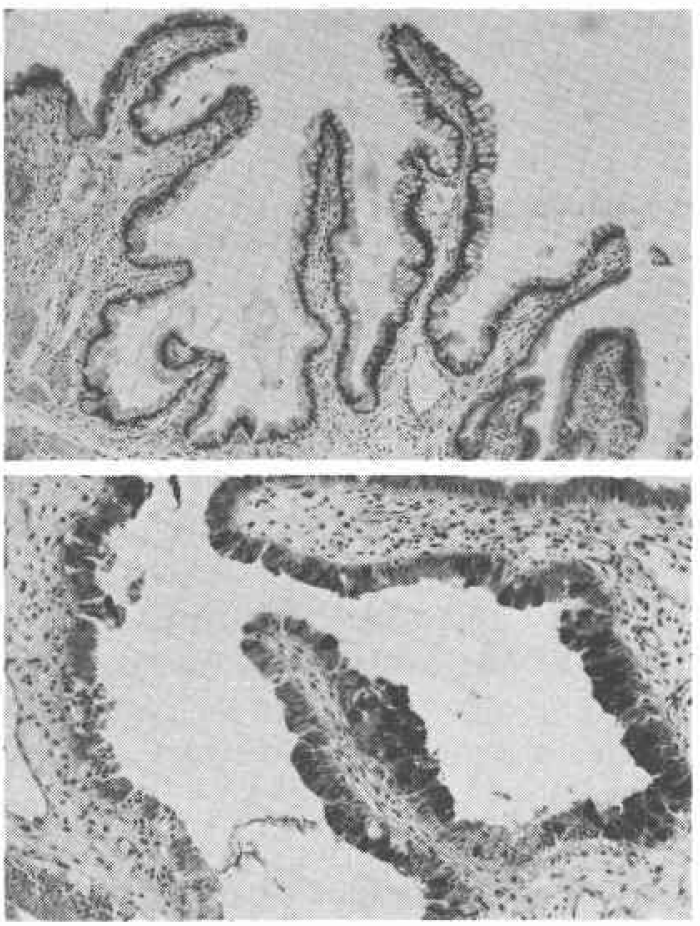

上粘膜は䋐毛状から乳頭状に増殖し杯細胞を伴っ ている (H-E 染色 $\times 50)$

下大きな粘液空胞が核及び 周囲細胞を王排 (PAS 染色 $\times 100$ ) 
写真 4 矢印は小皮縁, 所謂腸型吸收上皮 (PAS 染 色 $\times 100$ )

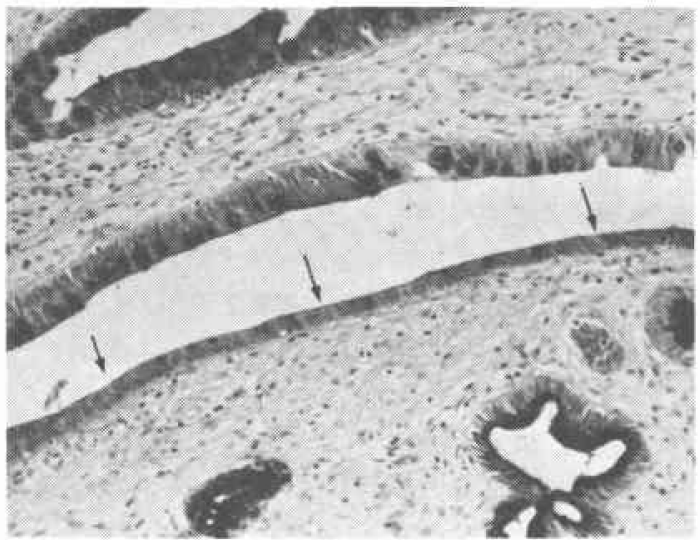

尚対照群では 1 例 $(10.0 \%)$ のみに認められ胆雍全体の 小粘液滴程度であった。13例のテステープ緑変部粘膜に は全例に明らかな杯細胞を認めた．部位別は表 4 に示す ごとくである．杯細胞は部位に差異はなく巣状に局所的 に認められることが多かったが，びまん性に多数の杯細 胞が広がっている症例もあった．そして杯細胞は単独に 認められることは少なく33例中30例（90.9\%）が為幽門 腺と合併していた。

しかし偽幽門腺よりも広く認められることはなく，か つ偽幽門腺の強い症例に杯細胞も多く認めることができ た，そのためか杯細胞を伴った部位は腺管も多く，胆譱 粘膜は絨毛状から乳頭状に増殖している例をみた（写克 3上). 杯細胞は粘膜表層や粘膜下層の腺管内に 認めら れ，その形態は胞体内に境界不明瞭な粘液滴を思わせる 末分化なるのから，明らかに alcianblue 陽性の粘液空 胞は認めるがいまだ核，括よび周囲細胞を王排していな いもの，大きな粘液空胞が核および周囲細胞を圧排し胃 にみられるのと同様の成熟杯細胞までさまざまであった

(写真3下)。 。た 3 例には PAS 染色陽性の小皮縁が 強く発達し，胞体に胆襄粘膜上皮特有の粘液顆粒を認め ないいわゆる腸型吸収上皮を思わせる腺管がみられた

(写臬 4 ).

ii ) 走查電顕的に検索

粘膜面の形態は走査電顕による観察で波状型が多く平 坦型もみられたが基本的に正常粘膜は六角形の刍の甲状 網目の構造を示していた（写京 5，6）。肉眼分類別に よる観察では

a ）肉眼分類 II 度 (写事 7)
写真 5 正常粘膜形態の波状型構造 $($ SEM 像 $\times 100)$

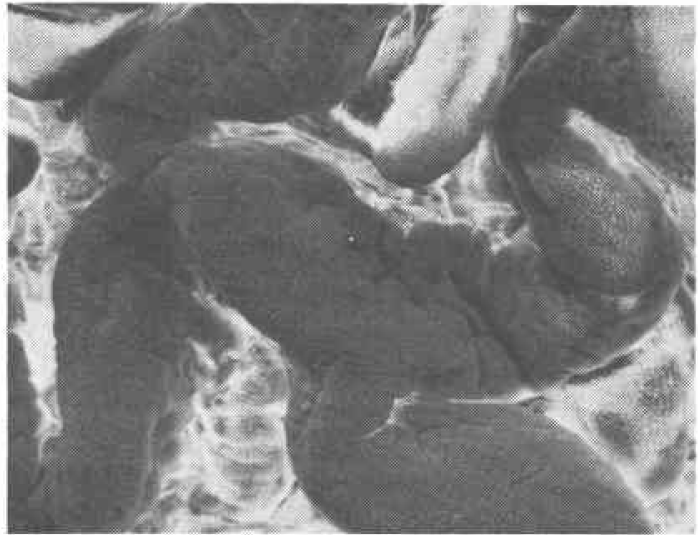

写真 6 正常粘膜の六角形龟の甲状網目構造 (SEM 像 $\times 6000)$

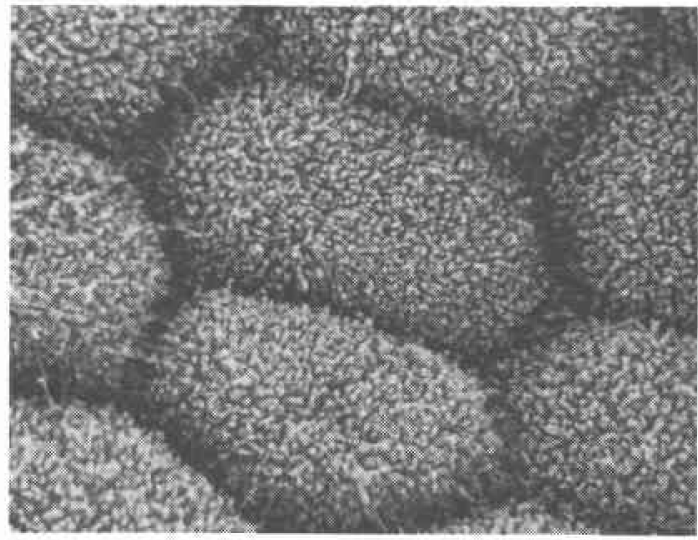

写真 7 肉眼 II 度六角形構造がやや形を異にしてさ ている。側面にも微䋮毛が存在 (SEM 像 $\times 2400)$

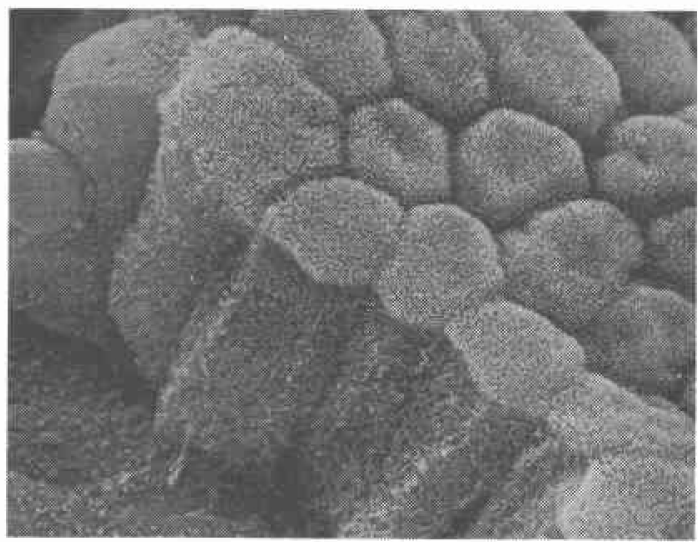


写真 8 肉眼 II 一度, 上皮細胞が不ぞろい, 六角 形, 五角形, 菱形, なすび形 (SEM 像 $\times 2400)$

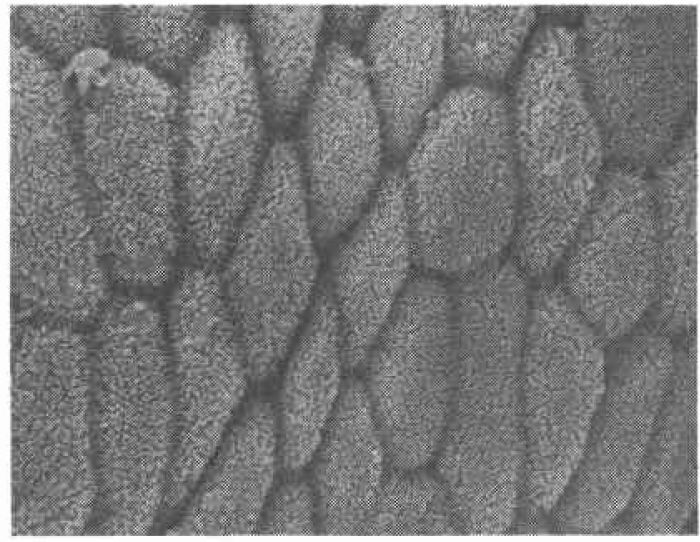

写真 9 肉眼 II 一面度細胞表面の中央部が微䄉毛を 欠いている。（SEM 像 $\times 6000 ）$

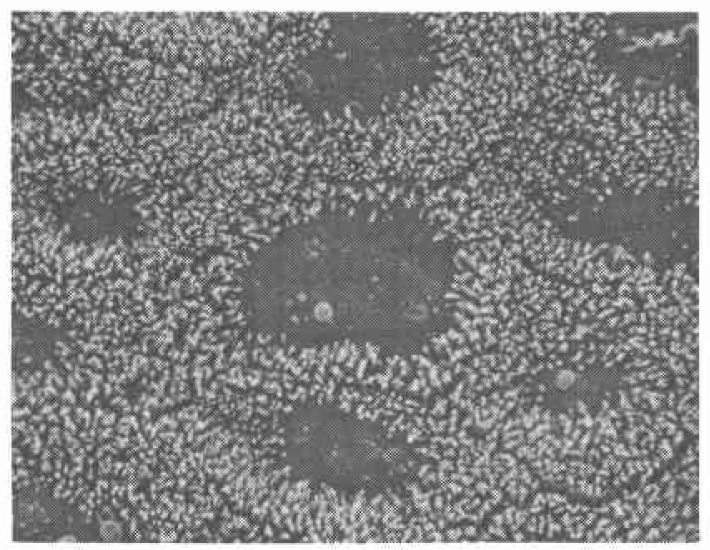

上皮は七ダに富み，蛇行，分枝，吻合によって複雑な 網目模様を呈していた. 個々の上皮はやや膨隆し，大部 分は 6 角形を呈していた。強拡大では上皮細胞の自由表 面は密生した微絨毛で被れていた．また細胞の側面にも 多くの微䋐毛が存在し，まれに腔に向って著しく突出し た細胞がみられた。

b ） 肉眼分類 II $\sim$ II 度（写真 $8 ， 9$ ）

各々上皮細胞の形が不ぞろい，すなわち六角形，五角 形，菱形またはなすび形などであった．また，細胞表面 の中央部が比較的滑らかで微緉毛を欠いでいる細胞がや や多く認められた. 恐らく粘液産生細胞への転化がうか がえるが粘液性の分泌顆粒の腔への放出は観察されなか った。
写真10 肉眼 III度, 粘液洧生細胞, 微䋐毛が少なく 表面が rough (SEM 像 $\times 6000)$

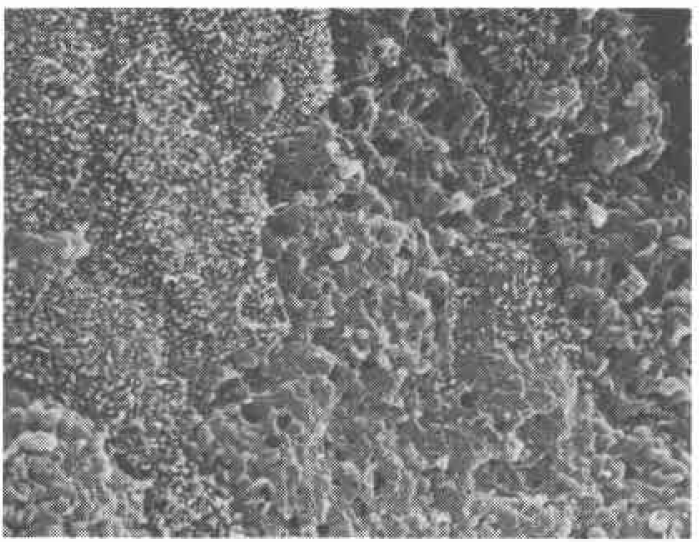

写真11 肉眼吕度, 粘液は開口分泌様式で放出 (EM 像 $\times 14,400)$

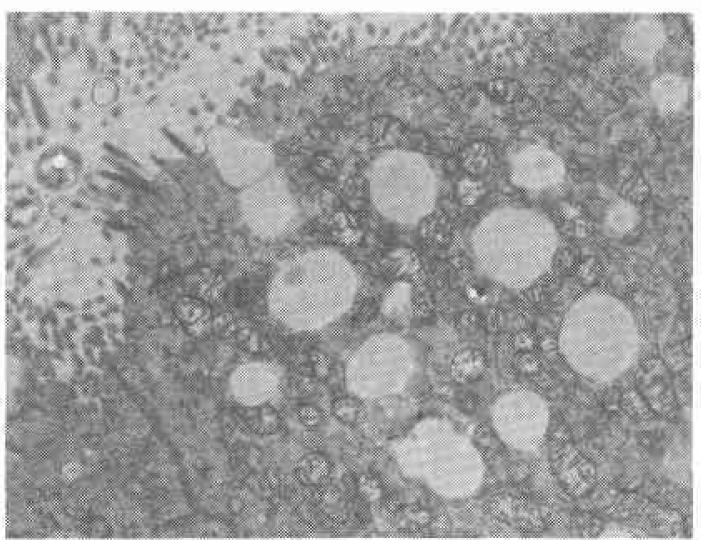

C) 肉眼的 III 度 (写真10)

microvilli の肥大あるいは癒合, 脱落, 細胞間の離 開，大小不同性から細胞が剥離するのが認められた。な おテステープ緑変部は程度の羑はあるが徽䄉毛が少なく 表面がざらざらした (rough) 細胞が多数観察された. これらの細胞が粘液産生細胞であり, 粘液顆粒の放出状 態もしばしば認められた．放出は透過電顕にて明らかな 開口分泌様式であった（写真11）

な和，肉眼IV度は粘膜欠損のため検討しなかった。

3）腸ク口ム親和細胞 (以下 $\mathbf{E}, \mathbf{C}$ 細胞之略す)

其12右, 表 $2 ， 3 ， 4$ )

HE 染色でやや暗い赤黄褐色に染まる分泌顆粒が核下 基底部に局在性に認められた. Grimelius 法和よび Mas- 
写真 12

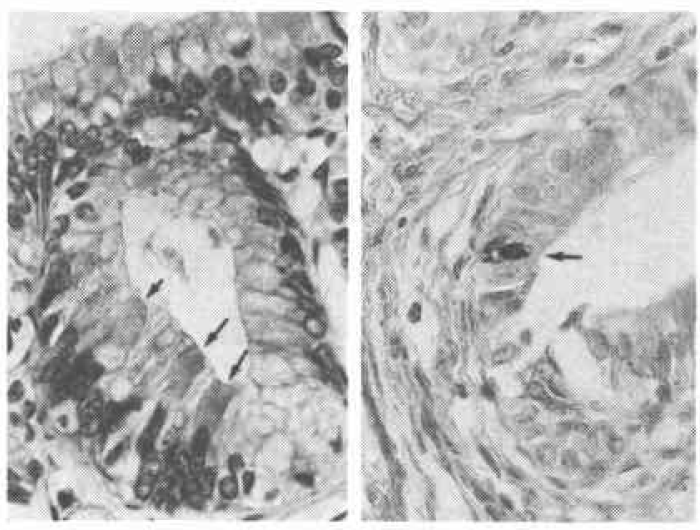

右 矢印, 腸ワロム親和䋖胞, 黒色の顆粒 (MassonFontana 染色)

左 矢印, Paneth 細胞, 顆粒が Eosin で赤染 (H-E 染色) $\times 400$

son-Fontana 法で検索した所，両染色にて黒色の顆粒が 染色され EC 細胞であることか゚判明した。この顆粒は 基底層のみならず核上部にも散見された．この EC 細 胞は後述の Paneth 細胞と同様, 胃および腸に比べきわ めて粗に散在性に存在していた. 肉眼的分類との対比で はやはり高度炎症症例に多かった（表 $3 ）$. なお対照群 には 1 例子認められなかった。

4) Paneth 細胞 (写真12左, 表 2, 3，4)

Paneth 細胞は検查例のわずか 3 例 $(2.9 \%)$ に認めら れ，対照群には認められなかった（表2）. その Paneth 細胞は胆䧶底部の肥厚部, 組織学的には EC 細胞, 杯 細胞，腸型吸収上皮ならびに偽幽門腺が強い増殖を示し た部分に認められ 1 例はあたか子 adenomyoma を思わ せる部の数力所に小さな集簇巣として認められた。 そし てそれらは集簇巣ではあっても散在性に孤立性に存在 し，小腸と胃の腸上皮化生巣にみられる様に相接して密
に存在することはなかった，細胞る立方状からやや丸み を帯びたものまでみられる、また，顆粒もEosin で赤 く赤染し 1 個 1 個が明瞭で明らかに Paneth 顆粒と判断 できるるのから，Eosin で淡くピンク色に一様に染色さ れ，顆粒の不明瞭なるのまでさまざまであった。このよ らに胆雍内の Paneth 細胞は明らかにそれと確認できる 成熟したものから，幼若な形態を示するのまでさまざま であるが，むしろ後者にその頻度が高かった。

D) 胆䔶癌の化生について（表 5 ）

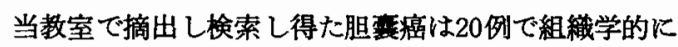
分類すると分化型腺癌16例（乳頭状腺癌 5 例，管状腺 癌11例)，低分化腺癌 3 例, Adenoacanthoma 1例であっ た. 著者はとくに分化型腺癌を中心に臨床病理学的に検 討した。

1) 肉眼像

不明 1 例を除く19例中隆起を示するのは15例, 残り 4 例は平坦であった．組織型別にみると分化型癌16例中13 例 (81.3\%) が隆起性となり残る 3 例は平坦であった. 低分化型癌は 1 例が不明で 2 例中 1 例 $(50.0 \%)$ が隆起 性, 1 例が平坦であり分化型癌に隆起性病変を示す傾向 が強かった。

2) 組織像

a ) 非癌粘膜の化生

非癌粘膜の珄状をみると杯細胞が分化型腺癌 16 例中 7 例 $(43.8 \%)$ にみられ 1 例は低分化腺癌の周囲にみられ た. 杯細胞は周囲細胞を王排したような成熟型や PAS$\mathrm{AB}$ 重染色に染まる小粘夜顆粒を含むむのおよび為幽門 腺との鑑別が困難な例までみられた。

b ）腫瘍内の化生

次に腫瘍内を詳細に検索すると, 分化型腺癌16例では 粘液空胞をむった所謂悪珄杯細胞を思わせたるのが12例 (75.0\%) に認められ低分化腺癌は 1 例であった（写志 13上下). また分化型腺癌には PAS 陽性に染まる小皮

表 5 摘出胆焉瘦20例の検索

\begin{tabular}{|c|c|c|c|c|c|c|c|}
\hline \multirow{2}{*}{ 組織型 } & \multirow{2}{*}{ 娭出例数 } & \multirow{2}{*}{ 男: 女 } & \multirow{2}{*}{$\begin{array}{c}\text { 平均年齡 } \\
\text { (歳) }\end{array}$} & \multicolumn{4}{|c|}{ 部位別症例数 } \\
\hline & & & & 全体 & 頝部 & 体部 & 底部 \\
\hline 分化型腺癌 & $16(80.0)$ & $6: 10$ & 54.0 & 4 & 7 & 1 & 4 \\
\hline 低分化型腺癌 & $3(15.0)$ & $0: 3$ & 58.0 & 1 & 1 & 0 & 1 \\
\hline 腺扁平上皮䈏 & $1(5.0)$ & $1: 0$ & 73.0 & 1 & 0 & 0 & 0 \\
\hline 全 症 例 & $20(100.0)$ & $7: 13$ & 55.6 & 6 & 8 & 1 & 5 \\
\hline
\end{tabular}


写真 13 上下共, 腫缶内悪性杯細胞 (H-E 染色上 $\times 400$ 下 $\times 100)$
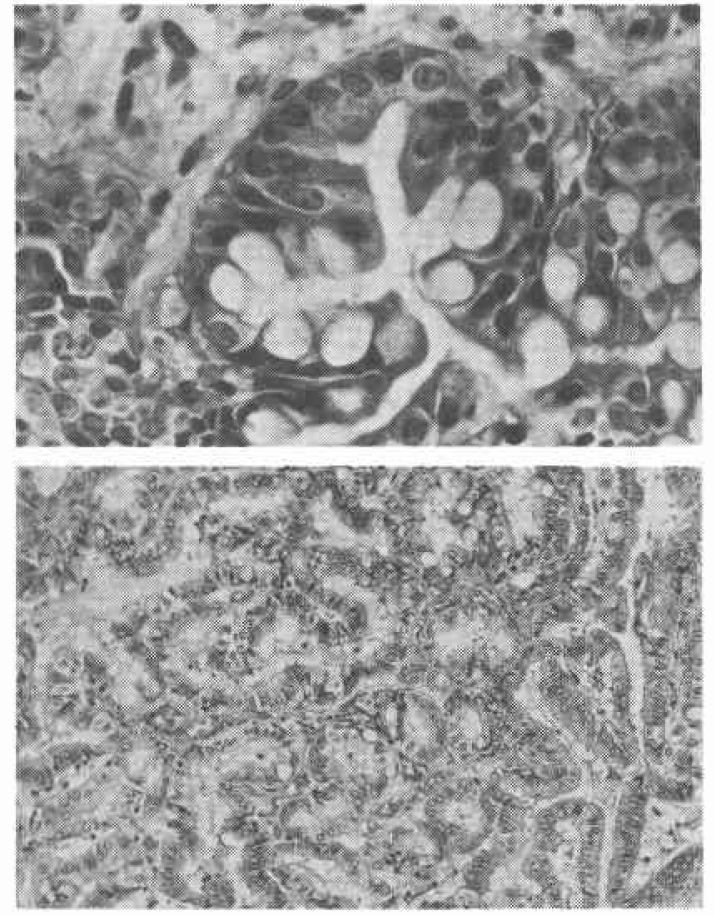

写真 14 矢印瘇瘍内小皮縁 $($ PAS 染色 $\times 50)$

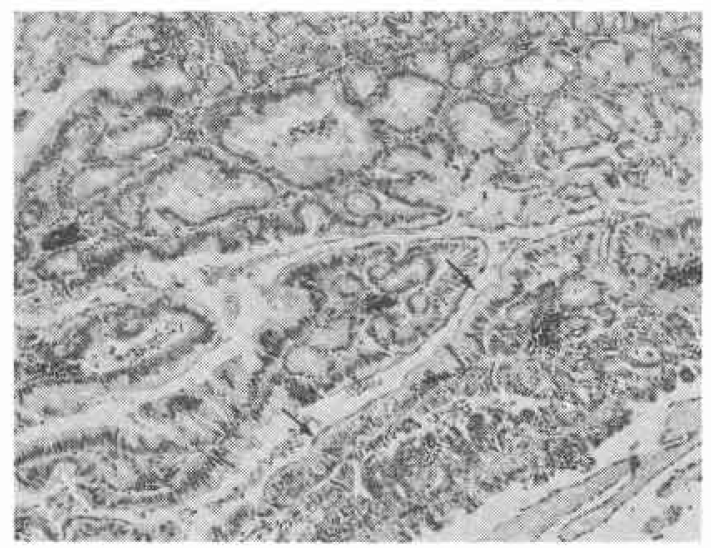

縁が腫瘍細胞内に認められた（写重14）。

\section{v) 考 察}

胆襄粘膜の変化を知ることは胆䧶癌の組織発生拉よび 早期䛦断のらえにきわめて重要と考兄られる.今日まで 胆衰粘膜の変化については多くの光顕的, 電䫒的研究が なされているが，最近松竽 ${ }^{3)}$, 小西 ${ }^{4)}$, Delaquerriere ${ }^{5)}$, $\mathrm{Järvi}^{6}{ }^{6}$, Laitio ${ }^{7}$, らは胆㖶炎で摘出した胆霊粘膜に幽門
化生, および杯細胞, EC 細胞や Paneth 練胞よりなる いわゆる腸上皮化生が起こることを報告している．腸上 皮化生は胃汇执いては一般的な所見であり，Morson帛は それを前癌状態と考兄, 中村”は“分化型癌は腸上皮化 生粘膜から，未分化型癌は胃固有粘膜から発生する”之 いら胃癌組織発生の概念を論じている。したがって胆衰 粘膜に杯細胞, EC 細胞, Paneth 細胞などの腸上皮化 生が発生すれば胃癌の概念から考学ても当然それらを母 地とする分化型癌, すなわち腸型胆囊癌の発生が推測で きる。

A) 胆襄の化生について

異所性組織（腸上皮化生や粘液腺）発見の報告は少な い. 異所性組織については最初 Aschoff $(1905)^{10)}$ が胆 粠底部に炎症を伴った所見として杯細胞および粘液腺 を報告している，その後 Nicholson (1923) ${ }^{11)}$ と Ansari $(1954)^{12)}$ は慢性炎症に伴う変化として，この粘液腺を幽 門腺あるいは Brunner 腺と等しいるのと考光たが，胎 児期の発育異常 (先天異常) を否定することができなか った.つぎに Jarvi (1962)1314) と Meurman (1964) はその粘液腺を化生変化であると報告している.腸上皮 化生は形態学的な立場から刷子縁, 杯細胞, EC 細胞, Paneth 細胞などの出現をもって定義づけられているが, 杯細胞の 報告はみるものの EC 細胞や Paneth 細胞, とくに Paneth 細胞についての報告はきわめて少い。 EC 細胞は Erspamer (1935) ${ }^{15)}$ が粘液腺とともに未分化 上皮から生じると報告し Gesswein (1959) ${ }^{16)}$ らにより 粘液分泌の旺盛な杯細胞分布域や粘液腺上皮間に数多く みられるとし今日まで間接化生に由来する変化として 考えられている. Paneth 細胞は Kerr 扣よび Lendrum

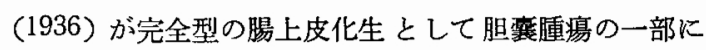
存在すると報告して以来, 腫瘍の内に存在したりあるい

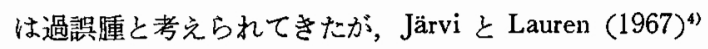
が化生機転により発生すると報告し大腸上皮に似ている とした，各種異所性組織について Laitio (1975) ${ }^{17)}$ は 電顕による検索を行い胃に拈ける腸上皮化生の因子と 同様，胆霊粘膜内に腸上皮化生があることを裏づけ， Kaye $(1973)^{18)}$ は円柱上皮細胞の 自由表面に多数の背 の高い不規則な Microvilli が存在したが，それは小腸 の吸収上皮細胞として規則的に配列した刷子縁を形ら゙く らず，むしろ大腸上皮に似ているとした。な扮本邦では 松峯 $(1978)^{3)}$, (1979 $)^{19)}$ が各種異所性粘膜組織仙つい て検索し胆囊が十二指腸と同し前腸系に属し腸上皮化生 と偽幽門腺が混在することから胆慗の化生を十二指腸化 
生とし発癌母地との関連性を考察している.

B ）化生の頻度および発生部位

胆襄に腸と同様の蔗糖分解酵素が存在すれば腸上皮化 生を証明したことになる。この目的でテステープを用い 生化学的に蔗糖分解酵素を証明しえた。この酵素は小腸 絨毛上皮の Microvilli に結合して存在しておりテープ による検索は粘膜表層に刷子縁をるった円柱上皮がある ことを示す．103例中13例の緑変がありこのことは胆裏 粘膜には大腸上皮ではなく小腸化生が12.6\%の頻度であ

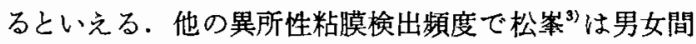
に差を認めず，年龄は著名な差がないとしているが，著 者の例においては表 2 に示すごとくやや女性に多く平均 年龄は全症例よりも 4 〜歳高龄であつた。だが対照群 は59.0歳と高齡にもかかわらず杯細胞扣よび為幽門腺が 各 1 例 $(10.0 \%)$ のみに存在したにすぎず，それる頝体 部に生じたごく未熟なものであつた。これらの組織は 異所性である点を無視すると正常な組織と区別できな い. 胃の腸上皮化生は加齢に伴い幽門腺前庭部小弯側か ら次第に胃体部およぶ一定の形式をとるが，胆囊におい ては年龄とは関係なく炎症（含結石）の存在した部位に 生じ胆衰全体に広がるすのと思われる. 表 4 に示すよう に胆襄全体，頝部，底部に核ぼ同頻度に 発生していた が，体部だけの発生はきわめて少なかった。なおコレス テロージスと腸上皮化生は両者に炎症所見があったが一.

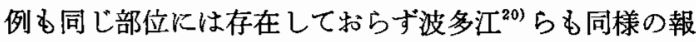
告をしている興味ある結果であった。

C）腸上皮化生構成成分およびその特微について

胃の腸上皮化生と対比して考えてみるに胆糞に生じた 化生巣は極端に腸型吸収上皮および Paneth 細胞が少 い.しかしそれらとテープ緑変例は小腸化生と考觉ても ほかのテープ不変例で杯細胞出現例は大腸化生とすべき なのか?，だが正常大腸には認められない偽幽門腺を多 くの症例で伴い大腸化生とも異ったもの之解される. 103例中小腸化生の構成成分から 考它た完全型は 3 例の みであり，そのほかは構成成分の不足した不完全型の腸 上皮化生と言わざるをえない。この不完全型は将来完全 型に成長する前段階とる考えられるが，胆䉴全割を施行 してもな捖全型を発見することがなかなかできないの は，未分化な状態を保ち不完全型はそのまま型を留める のではないかと考觉る．また成熟度からみると EC 細 胞および Paneth 細胞は特に未熟な症例が多く, 密生し て存在することはきわめてまれである。このように胆䙵 の腸上皮化生は不完全型で未熟な症例が汷とんどで不安
定状態にあると考えられる。胆変に批ける異所性組織は 腸上皮化生と為幽門腺を一諸に考えることもできるが， 胃の幽門部を例にとってみると正常では増殖細胞帯は腺 の中央部に位置し, 僈性炎症反応の結果本来の増殖細胞 带の高さの部位に化生上皮の増殖帯が形成される。杯細 胞等は上方に成長していくが正常の増殖細胞帯は次第に 下降していき，急に固有腺細胞が失われた時などはすで に増殖細胞帯より作り出されて下方へ細胞移動を行って いる幼若主細胞が堌殖して粘液細胞を作り出す. いった ん分化度の低い粘液細胞が形成されれば不可逆的な変化 であると言われている。このように両者は炎症により発 生するようであり松等 ${ }^{39}$ は腸上皮化生と粘液腺が同一部 位に分布しやすく，一つの巣を形成することが多いし， その形態は十二指腸粘膜にちかく, また, 両者の非併存 巣についても十二指腸と見なすことが可能であると述べ ている.だが発生する場所が多少異っており分化型胃癌 は腸上皮化生から発生するとする中村 ${ }^{73}$ の概念を考兄る と腸上皮化生と偽幽門腺を同一化生として考えるよりむ 両者を分けるべきであると考元る。

胃において腸上皮化生は幽門腺領域に発生し，胃底腺 領域には認められていない。これは胆翼においても杯 細胞が単独では認められることは少なく，33例中30例 (90.9\%) が幽門腺と合併していた結果とほぼ一致 するむのであった。

偽幽門腺は肉眼分類 II 度に19例 (70.4\%) と最もその 頻度が高くこのことからも偽幽門腺と晹上皮化生は炎症 との強い関連性が想像される. したがつて両者は細胞の 欠損あるいは粘膜の変性虽離脱落などといったあくまで も組織構造の破壊といら刺激に対し, 再生分化異常を生 じて発生し，抵抗減少部に粘液を産生することにより炎 症を柔らげようとして化生がおこるる考えられた。

D）胆震癌と化生の関係

孔乙胃癌の場合と同様に胆鸾腸上皮化生粘膜が分化型 癌発生に「関係があるらしい」とすれば両者には，肉眼 像や光顕学的に類似点をるつかも知れない。このような 観点から検討を加えた。

a) 肉眼像

分化型癌の $81.3 \%$ は隆起性病変であったが，これは胃 にみられる所謂腸型癌と同じ形態である。な替在癌 3 例はいずれる肉眼分類吕度であり腸上皮化生の高頻度に 発生する粘膜と同じ所見であった。

b ) 光顕学的

もし腸上皮化生からの癌化が存在するとすれば一般腫 
瘍病理学の根底に横たわる基本的概念「腫場はそれが発 生した喴器の構造, 機能を多少とも模做している」から 考えて両者に何らかの形態学的類似性があるはずであ る. 杯細胞は有石胆襄炎症例 (32.0\%) 上りる分化型腺 癌非癌粘膜 $(43.8 \%)$ 队腫瘍内 $(75.0 \%)$ 亿高頻度に認 める。そして分化型癌には腸型吸叹上皮が認められ，ま た 1 例ではあるが分化型癌周囲粘膜のテステープ緑变例 があり, 松䋅 ${ }^{19}$ は17例の胆囊癌について検索し非癌粘膜 に 8 例 $(47.1 \%)$ ，腫瘍内に 3 例 $(17.6 \%)$ のC 細胞 を発見している．このことを考方合わせると分化型胆 癌は腸上皮化生から発生した可能性を考察できるもので ある.な打低分化腺癌 1 例杯細胞を認めた。これは進 行癌例であり同一腫瘍内に組織多様性があり初期癌のよ らな一様な形態をして执らず二次的な修飾像，あるいは 時間の経過とともに粘膜の腸上皮化生が進んだとも考兄 られるが，その確かな病原は不明であった。

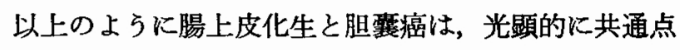
があり中村”らが記述しているょうに化生は前癌状態で あると疑らことるできうる.ではなぜ化生から癌化への 道をたどるのか．それは胆䨢腸上皮化生が特に不完全型 をとり，未熟な細胞が多くこの不安定状態は，特殊な異 所性上皮が形成されるという現象だけでなく，この環境 に細胞分化の抑制や細胞回転の亢進さらにアンバランス な細胞回転等が生じ癌化するのだと考えたい。

\section{VI) 結 語}

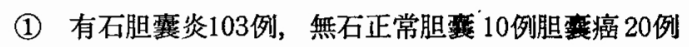
についての腸上皮化生とそれからの癌化について検索し た.

(2) 摘出胆锤粘膜を肉眼的にその病変の程度により正 常上り高度胆䧶炎まで I IV度に分類した. II 度が56例 (54.4\%) と最子多かった. 肉眼所見と走查電顕所見は その粘膜病変程度がほ注一致していた。

(3) テステープによる化生を検索し蔗糖分解酵素を発 見した．それは13例（12.6\%）に見られ女性に10例之高 頻度であり肉眼分類 II 度は $37.0 \%$ が緑変した。緑変例は 全て杯細胞が存在していた. 対照群は 1 例も緑変はなか った.

(4) 有石胆襄炎103例中偽幽門腺55例 $(53.4 \%)$, 杯細 胞33例 $(32.0 \%), \mathrm{EC}$ 紐胞12例 $(11.7 \%)$, Paneth 細 胞 3 例 (2.9\%) の出現を見，いずれも炎症高度症例の III度に発生率が高かった。 対照群は隐幽門腺, 杯細胞が 各 1 例 $(10.0 \%)$ の出現であった.

(5) 偽幽門腺は腺窩深く発達し, 逆に杯細胞は上方に
発育して90.9\%が偽㓜門腺と合併していた.

(6) Paneth 細胞および EC 細胞は末熟なものが多か った。また 3 例に腸型吸収上皮を思わせる腺管がみられ た.

(7) 腸上皮化生発生には加㱓変化よりる結石等による 炎症が重要と思われ，発生部位に胃のような一定の形式 はなかった。

（8) 腸上皮化生の発生部位は䅡部叔よび底部に多かっ た.

(9) 分化型癌16例中非癌粘膜に杯細胞が 7 例 (43.8 $\%)$, 腫崵内に 12 例 $(75.0 \%)$ と杯細胞が高頻度に認め られ，腸型吸収上皮の存在するものがあった。

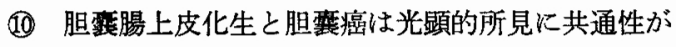

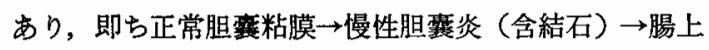
皮化生 $\rightarrow$ 分化型胆㖶癌 (腸型癌) を生じうる可能性が考 察できた。

稿を釉るにあたり御指導と御校閲を賜わった恩師古贺 道弘教授に深謝すると共に, 本研究について直接御指導 をいただいた本学第二外科中山和道助教授並びに内藤寿 則助手に深謝いたします。また電䫒的検索に際し釉始御 指導をいただいた大分大学第 II 解剖学島田達生助教授に 深謝いたします。

（本論文の一部は第20回日本消化器病学会秋季大会お よび13回日本消化器外科学会総会等において発表した.)

\section{文 献}

1）田中宣威他：胃腸上皮化生のテステープによる 迅速かっ正確な検出法. 胃と腸，6（12）： 1593-1601, 1971.

2) 今永一他：結石を有する胆露の前癌状態につ いて。癌の臨床, 1 (3) : 241-255, 1955.

3）松崒敬夫他：慢性胆篦粘膜の化生.日消病会 誌, 75 (5) : 674-685, 1978.

4) 小西二三男他：腸上皮化生型慢性胆簬炎の蹦床 病理学的検討. 日病理会誌, $270-271,1977$.

5) Delaquerriere, L., et al.: Argentaffine cells in chronic cholecystitis. Arch. Path., 74: 142157, 1962.

6) Järvi, O., et al.: Intestinal metaplasia in the mucosa of the gallbladder and common bileduct. Ann. Med. Exp. Fenn., 45: 213-223, 1967.

7) Laitio, M.: Intestinal, gastric body and antral-type mucosal mucosal metaplasia in the gallbladder. Beitr. Path. Bd., 159: 271-279, 1976.

8) Morson, B.C.: Carcinoma arising from areas of intestinal metaplasia in the gastric mucosa. 
Brit. J. Cancer., 9: 377-385, 1955.

9) 中村恭一他：胃癌の組樴発生, 原発性微小胃癌 を中心とした胃癌の光顕・電影的ならびに統計 的研究. 癌の臨床, 15：627-647, 1969.

10) Aschoff, L.: Bemerkungen zur pathologischen anatomie der cholelithiasis und cholecystitis. Uerhandl. Deutsch. Path. Ges., 9: 41-48, 1905.

11) Nicholson, G.W.: Heteromorphoses (metaplasia) of the alimentary tract. J. Path. Bact., 26: $399-417,1923$.

12) Ansari, I.H.: Papillom der gallenblase mit magenschleimhautepithelien. Zbl. Allg. Path., 92: $355-359,1954$.

13) Järvi, O.: A review of the part played by gastro-intestinal heterotopias in neoplasmogenesis. Proc. Finnish. Acard. Sci. Lett., 151-187, 1962.

14) Järvi, O.: Heterotopic gastric mucosa and pancreas in the gallbladder with reference to the question of heterotopias in the general ann.
Acard. Sci. Fenn. Ser. A $106(22): 1-42$, 1964.

15) Erspamer, V.: Die enterochromaffinan zellen der gallenwege in normalen und pathologischen. Zuständen. Virchow. Arch. Path. Anat., 297: 70-92, 1936.

16) Gesswein, M.: Über heterotope magenschleimhautiseln in gallenblasen und darm. Zbl. Allg. Path., 99: 131-135, 1959.

17) Laitio, M.: An electron microscopic study of intestinal metaplasia in human gallbladder beitr. Path. Bd., 155: 297-308, 1975.

18) Kaye, G.I.: Comparative electron microscopic features of normal. Hyperplastic, and adenomatous human colonic epithelium. Gastroenterology, 64: 926-945, 1973.

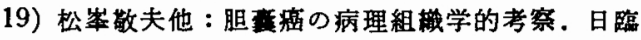
外会誌, 39回 6 号：927-934, 1979.

20）波多江康用他：化生上皮をもつ胆零にみられた びまん性 papillomatous cholesterosis $の 1$ 例. 胃と腸，13（5）：695-700，1978. 